\title{
RECONNAISSANCE INVESTIGATION OF THE GEOLOGY AND HYDROGEOLOGY OF LACKLAND AIR FORCE BASE, SAN ANTONIO, TEXAS
}

By George B. Ozuna and Ted A. Small

U.S. GEOLOGICAL SURVEY

Water-Resources Investigations Report 93-4037

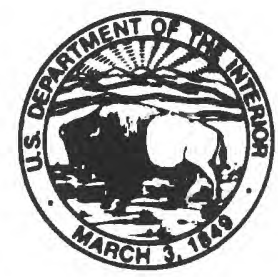

Prepared in cooperation with the

U.S. AIR FORCE, AIR TRAINING COMMAND, RANDOLPH AIR FORCE BASE, TEXAS

Austin, Texas 


\section{U.S. DEPARTMENT OF THE INTERIOR \\ BRUCE BABBITT, Secretary}

U.S. GEOLOGICAL SURVEY

Robert M. Hirsch, Acting Director

U.S. Geological Survey

District Chief

8011 Cameron Rd.

Austin, TX 78754-3898
U.S. Geological Survey ESIC, Open-File Reports Section

Box 25286, Mail Stop 517

Denver Federal Center

Denver, CO 80225-0046 


\section{CONTENTS}

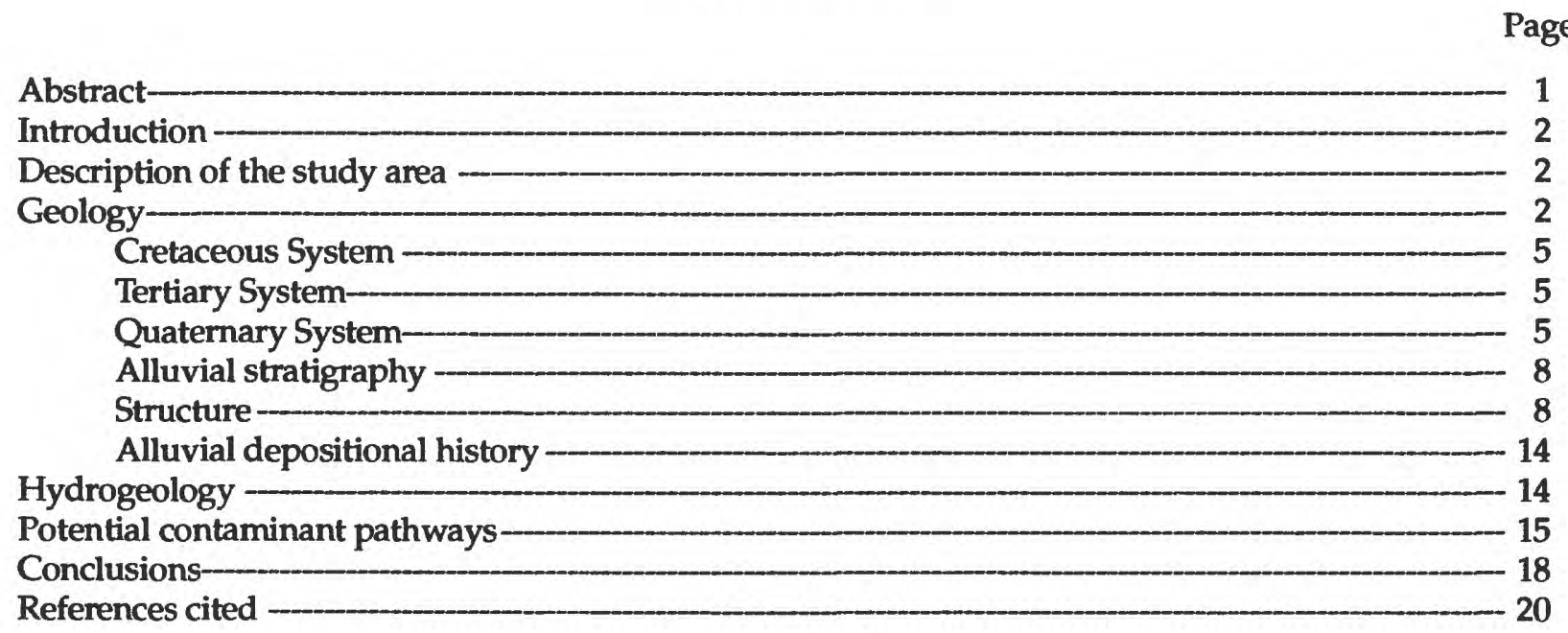

\section{ILLUSTRATIONS}

Figures 1-7. Maps showing:

1. Location of the study area

2. Geology in the vicinity of Lackland Air Force Base and Medina Base

3

3. Alluvial geology in the vicinity of Lackland Air Force Base and Medina Base -____ 7

4. Top of the Leona Formation at Lackland Air Force Base _- 9

5. Thickness of the Leona Formation at Lackland Air Force-_-_ 10

6. Top of the fluviatile terrace deposits at Medina Base-___ 11

7. Thickness of the fluviatile terrace deposits at Medina Base-___ 12

8. Diagrammatic geologic section in the vicinity of Lackland Air Force Base and Medina Base

9-10. Maps showing water levels in wells completed in the:

9. Leona Formation at Lackland Air Force Base, summer 1988

10. Fluviatile terrace deposits at Medina Base, summer 1988 17

\section{TABLE}

Table 1. Summary of the lithology of the geologic units in the vicinity of Lackland Air Force 
. 


\section{CONVERSION FACTORS AND VERTICAL DATUM}

\begin{tabular}{lll}
\hline \multicolumn{1}{c}{ Multiply } & By & To obtain \\
\hline foot $(\mathrm{ft})$ & 0.3048 & meter \\
gallon per minute (gal/min) & 0.06308 & liter per second \\
mile (mi) & 1.609 & kilometer \\
\hline
\end{tabular}

Sea level: In this report,"sea level" refers to the National Geodetic Vertical Datum of 1929 (NGVD of 1929)--a geodetic datum derived from a general adjustment of the first-order level nets of the United States and Canada, formerly called Sea Level Datum of 1929. 


\title{
RECONNAISSANCE INVESTIGATION OF THE GEOLOGY AND HYDROGEOLOGY OF LACKLAND AIR FORCE BASE, SAN ANTONIO, TEXAS
}

\author{
By George B. Ozuna and Ted A. Small
}

\begin{abstract}
An investigation at Lackland Air Force Base and Lackland Air Force Base Training Annex (Medina Base) was conducted from May to September 1988 to delineate the subsurface geology, to describe the hydrogeology within the study area, and to determine possible migration pathways for contaminants. Data from this investigation supplement data collected in conjunction with other Air Training Command studies conducted under the Installation Restoration Program.

The geologic formations in the vicinity of Lackland Air Force Base and Medina Base consist of sedimentary rocks of Cretaceous, Tertiary, and Quaternary age. The lithology of these formations consists primarily of limestone and marl, with lesser amounts of gravel, sand, silt, shale, and clay. The formations that comprise the geologic setting at Lackland Air Force Base and Medina Base include the Navarro Group of Late Cretaceous age, the Midway Group and Uvalde Gravel of Tertiary age, and the Leona Formation and fluviatile terrace deposits of Quaternary age.

The age of the faulting within the study area has not been determined accurately, but the faulting might have occurred during intervals from Early Cretaceous to Holocene time. During these tectonic episodes, uplift of the Edwards Plateau might have occurred. This uplift could have enhanced erosion of the Cretaceous age Edwards Group, which is north of the study area, causing deposition of alluvial deposits south of this tectonic activity. The Leona Formation is composed of limestone gravel deposits forming terraces in the valleys of present streams. In general, these terraces are topographically lower than those formed by the Uvalde Gravel. In contrast, the fluviatile terrace deposits are above flood level along entrenched streams such as Leon and Medio Creeks. The Leona Formation is generally above the level of these fluviatile terrace deposits.

A review of the hydrogeologic literature indicated that the Navarro and Midway Groups do not yield water to wells in Bexar County. However, recent studies by the U.S. Geological Survey at Kelly Air Force Base indicate that the uppermost beds of the Navarro Group can be saturated but yield little or no water to wells. Each stream terrace deposit of the Leona Formation and the fluviatile terrace deposits are separate water-bearing units. At Lackland Air Force Base, shallow ground water is present in the Leona Formation and the flow probably is toward Leon Creek. At Medina Base, the fluviatile terrace deposits are present along both banks of Medio Creek and probably are separate water-bearing units. Furthermore, ground-water flow in each of these units probably is toward Medio Creek. The Uvalde Gravel, present only at and west of Medina Base, is not a source of shallow ground water. However, during periods of precipitation, the formation can readily absorb precipitation and surface runoff. Water drains quickly through the formation because of its topographically high position and substantial hydraulic conductivity.

Major pathways of potential contaminant migration off the bases include the local streams of Medio and Leon Creeks, and to a lesser extent, the shallow ground water beneath the bases. Although the Uvalde Gravel is not a source of shallow ground water at Medina Base, it drains water quickly, and wastes that might be buried in the gravel could be a potential source of contamination during brief ground-water recharge periods resulting from major precipitation.
\end{abstract}




\section{INTRODUCTION}

A reconnaissance investigation to delineate the subsurface geology and describe the hydrogeology at Lackland Air Force Base (AFB) and Lackland AFB Training Annex (Medina Base) and to determine possible migration pathways for contaminants was conducted from May to September 1988 by the U.S. Geological Survey, in cooperation with the U.S. Air Force, Air Training Command, Randolph AFB. A literature review of all readily available geologic information and previous studies at Lackland AFB and Medina Base and examinations of geologic formations that crop out in the study area were performed as part of the investigation. The scope of the investigation was limited to defining the location and extent of shallow ground water in alluvial sediments at both military bases.

This report describes the results of a reconnaissance investigation of the geology and hydrogeology of the surface and shallow subsurface at Lackland Air Force Base and Medina Base. The data in this report are limited to that provided by test borings and water wells at the two bases, a geological and foundation investigation by the U.S. Army Corps of Engineers, and the surface geologic investigations by the authors.

Available data on the geology and hydrogeology were compiled and analyzed to aid in the preparation of all geologic structure and thickness maps. Thickness maps were prepared from monitoring well control points, and supplemental control points were determined by superimposing structural contour maps of the two bounding datum horizons and computing the difference in elevations at points where the two sets of contours intersect. A water-level measurement was attempted in 28 monitoring wells that had been drilled as part of previous Installation Restoration Program (IRP) investigations at Lackland AFB and Medina Base. Only nine of the monitoring wells had a water level that could be measured. These nine water-level measurements were used to prepare the water-level maps for each individual water-bearing unit.

Data from this investigation supplement data collected in conjunction with the Air Training Command's IRP to identify the most likely migration pathways of contaminants, to assess danger to human health, and to guide additional IRP work, if needed. Geologic and hydrogeologic information that improves understanding of flow in the shallow ground-water system is essential for evaluation and selection of remedial actions on sites where contamination might occur.

\section{DESCRIPTION OF THE STUDY AREA}

Lackland AFB and Medina Base are located in west-central Bexar County (fig. 1) and lie within the Gulf Coastal Plain physiographic province. The Gulf Coastal Plain consists of gently rolling plains and moderately hilly country, underlain by limestones, marls, sands, and clays. The interstream surfaces are broad flats whose only relief is shallow basins caused by unequal drying and shrinkage of the calcareous clays (Fenneman, 1938). Surface altitudes range from $780 \mathrm{ft}$ above sea level along the western boundary of Lackland AFB, to $620 \mathrm{ft}$ above sea level at Medina Base along Medio Creek.

Lackland AFB is drained by Leon Creek. The Leon Creek watershed is located in the western part of Bexar County. Leon Creek originates in the northwestern part of Bexar County and flows southerly to its junction with the Medina River. Most of Medina Base is drained by Medio Creek. The Medio Creek watershed is located in west-central Bexar County. Medio Creek originates along the central part of the BexarMedina County line and flows southeast, through Medina Base, to its junction with the Medina River. Leon and Medio Creeks and the Medina River are shown in figure 1.

\section{GEOLOGY}

The geologic formations that crop out in the vicinity of Lackland AFB and Medina Base are sedimentary rocks of Cretaceous, Tertiary, and Quaternary age. The lithology of these formations consists primarily of limestone and marl with lesser amounts of gravel, sand, silt, shale, and clay. A summary of the lithologies of the geologic units is given in table 1. The dip of the beds is generally to the south and southeast. 


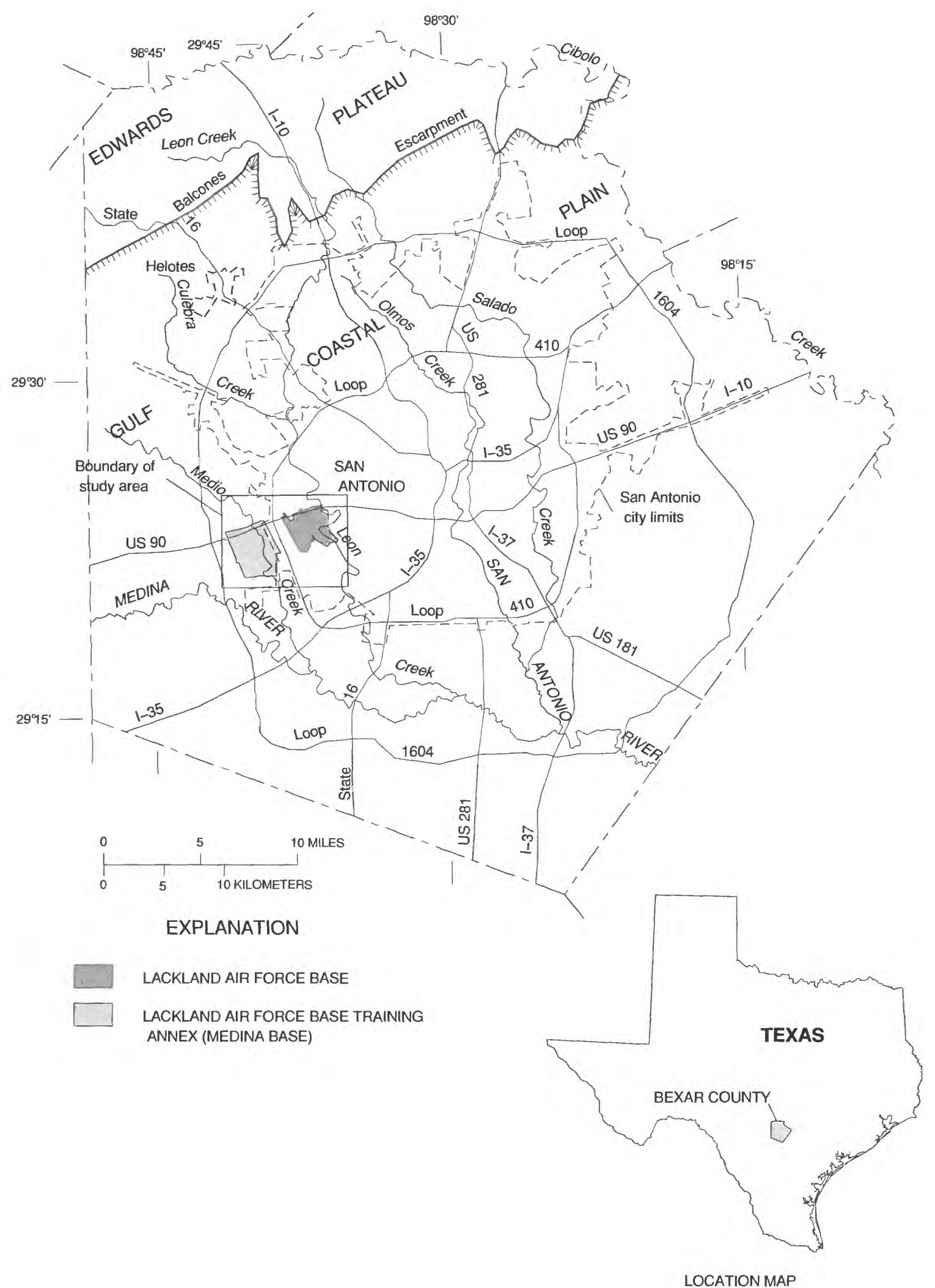

Figure 1. Location of the study area. 
Table 1. Summary of the lithology of the geologic units in the vicinity of Lackland Air Force Base

\begin{tabular}{|c|c|c|c|c|c|}
\hline System & Series & Group & Formation & $\begin{array}{l}\text { Thickness } \\
\text { (feet) }\end{array}$ & Lithology \\
\hline \multirow{2}{*}{ Quaternary } & Holocene & & $\begin{array}{l}\text { Fluviatile } \\
\text { terrace } \\
\text { deposits }\end{array}$ & $0-25$ & $\begin{array}{l}\text { Gravel, sand, silt, and } \\
\text { clay. }\end{array}$ \\
\hline & Pleistocene & & Leona & $0-26$ & $\begin{array}{l}\text { Calcareous silt grading } \\
\text { downward into a coarse } \\
\text { gravel. }\end{array}$ \\
\hline \multirow{3}{*}{$\begin{array}{l}\text { Tertiary or } \\
\text { Quaternary }\end{array}$} & $\begin{array}{l}\text { Pliocene or } \\
\text { Pleistocene }\end{array}$ & & $\begin{array}{l}\text { Uvalde } \\
\text { Gravel }\end{array}$ & $5-20$ & $\begin{array}{l}\text { Caliche-cemented } \\
\text { chert gravel. }\end{array}$ \\
\hline & \multirow{2}{*}{ Paleocene } & \multirow{2}{*}{ Midway } & $\begin{array}{l}\text { Wills } \\
\text { Point }\end{array}$ & $5-490$ & $\begin{array}{l}\text { Sandy clay containing } \\
\text { sandy or limy concre- } \\
\text { tions. }\end{array}$ \\
\hline & & & Kincaid & $100-150$ & $\begin{array}{l}\text { Sandy limestone upper } \\
\text { part; glauconitic, } \\
\text { sandy shale in lower } \\
\text { part. }\end{array}$ \\
\hline \multirow{2}{*}{ Cretaceous } & \multirow{2}{*}{ Gulfian } & \multirow{2}{*}{ Navarro } & Escondido & $0-30$ & $\begin{array}{l}\text { Calcareous to argilla- } \\
\text { ceous sandstone. }\end{array}$ \\
\hline & & & Undivided & $400-450$ & $\begin{array}{l}\text { Calcareous clay and } \\
\text { marl. }\end{array}$ \\
\hline
\end{tabular}




\section{Cretaceous System}

The oldest geologic unit at Lackland AFB and Medina Base is the Navarro Group of Late Cretaceous age (fig. 2). In Bexar County, the Navarro Group is mainly a calcareous clay and marl about $450 \mathrm{ft}$ thick. The Navarro Group, as described by Brucks (1927), is a mostly bluish-gray calcareous clay. The uppermost beds consist of similar clays interbedded with cross-bedded and evenly bedded, very fine-grained, variably indurated, calcareous to argillaceous sandstones that are light blue when fresh, and weather to a grayish-yellow color. In the University of Texas, Bureau of Economic Geology (1983) report, the lower part of the Navarro Group is described as an unctuous, greenish-gray to brownish-gray clay.

The uppermost beds of calcareous clay of the Navarro Group pinch out in western Bexar County and the northern part of Medina Base. Throughout the remainder of western Bexar County and in all of Medina County, upper parts of the Navarro Group are represented by the Escondido Formation. A small outlier of the Escondido is present along Medio Creek on Medina Base (fig. 2). The Escondido Formation, as described by Holt (1959), consists of flaggy, gray calcareous to argillaceous fine-grained sandstone, thinbedded orange-yellow siltstone, gray to bluish-gray shale, and layers or lenses of sandy marl and limestone. Fossils include Exogyra costata and Sphenodiscus. The outcrop of the Escondido Formation in the northeastern part of Medina Base (fig. 2) contains numerous Exogyra costata.

\section{Iertiary System}

The close of the Cretaceous period was marked by elevation of the land and retreat of the sea throughout central Texas. Early Tertiary time began with a new transgression of the sea. The Midway Group of Tertiary (Paleocene) age unconformably overlies the Navarro Group in the central part of Lackland AFB and Medina Base (fig. 2). It consists of two formations; in ascending order, these are the lower Kincaid Formation and the Wills Point Formation. Also included in the Tertiary System is the Uvalde Gravel, which is an abandoned stream terrace deposit of Pliocene age.

Holt (1959) reported that the Kincaid Formation at its base is marked by phosphate nodules and reworked sands and pebbles of the Escondido Formation. Holt describes the Kincaid Formation as a glauconitic, sandy, greenish-gray shale overlain by an impure glauconitic, sandy, yellowish-gray limestone containing pyrite nodules. The presence of these glauconitic limestones and sands was confirmed by examination of outcrops north of Billy Mitchell Road and west of Leon Creek. Further confirmation of the existence of the glauconitic sands came from the review of $\log$ descriptions of borings from two independent studies by McIntosh and Behm (1967) and URS Consultants (1988).

The Wills Point Formation, as described by Arnow (1959), consists mainly of sandy clay containing many sandy or limy concretions. The clays are a greenish gray and weather to a yellow brown. This coloration of the clays within the Wills Point Formation is similar to that of the upper formation of the Navarro Group. This similarity in color might cause difficulty in discerning one formation from the other in the field. The important distinction is that the Wills Point Formation clays do not have the unctuous texture that is associated with the Navarro Group clays.

The Uvalde Gravel is the oldest and highest terrace deposit in Bexar County. As described by the University of Texas, Bureau of Economic Geology (1983), the Uvalde Gravel is a caliche-cemented chert gravel with some boulders up to $1 \mathrm{ft}$ in diameter. The gravel consists of well-rounded cobbles of chert and some cobbles of limestone and quartz. The Uvalde Gravel has a characteristic red color because of a coating of iron oxide on the boulders and pebbles. Holt (1959) reported a maximum thickness of $20 \mathrm{ft}$ in Medina County. In soil borings at IRP sites on Medina Base, the Uvalde Gravel is 10 to $15 \mathrm{ft}$ thick (URS Consultants, 1988). The outcrop pattern of the Uvalde Gravel in the vicinity of Medina Base is shown on the alluvial geology map (fig. 3).

\section{Quaternary System}

The Leona Formation of Pleistocene age and the fluviatile terrace deposits of Holocene age are part of the Quaternary System present in the study area. Both units are stream terrace deposits composed of unconsolidated alluvium produced by downcutting of the flood plain. 


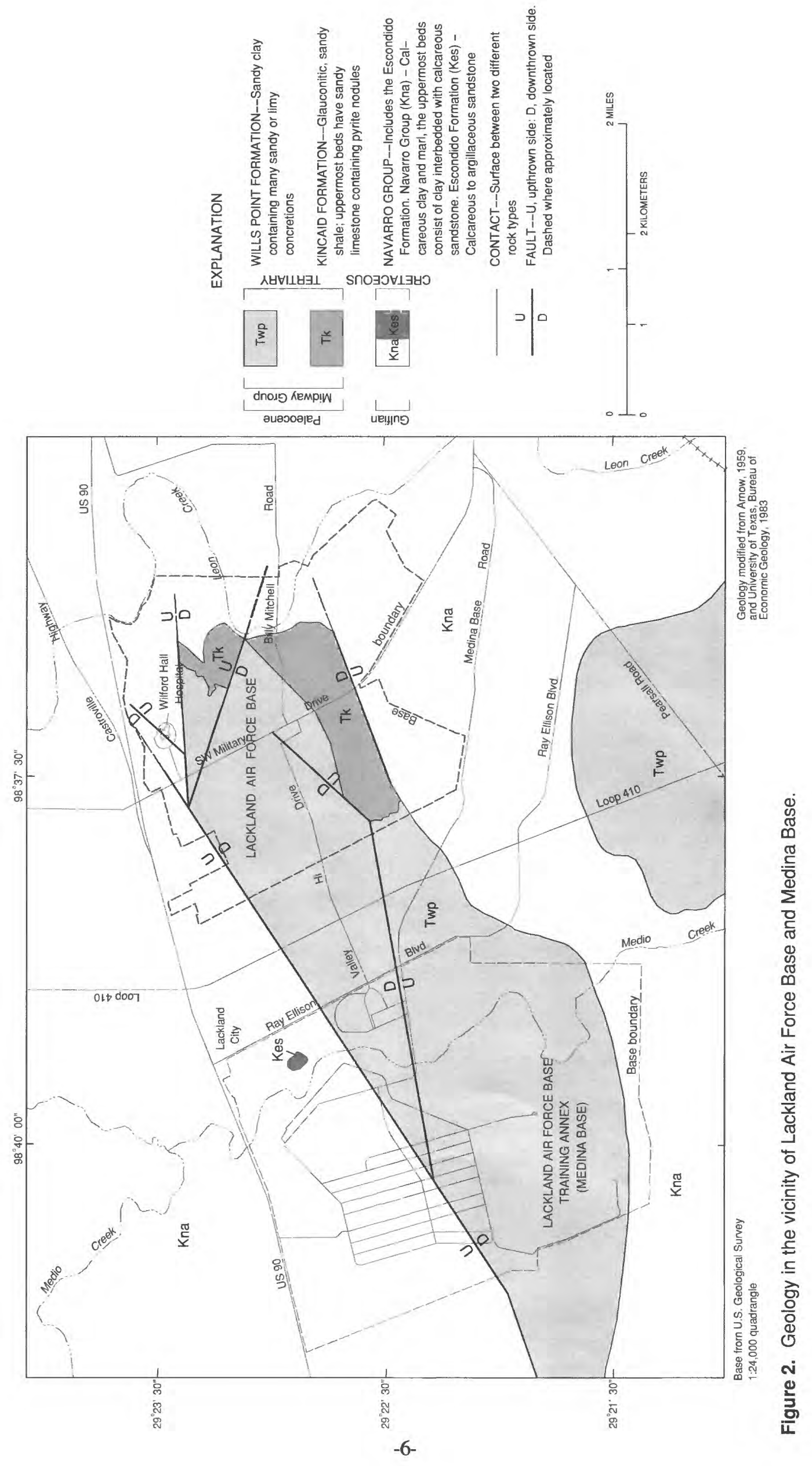



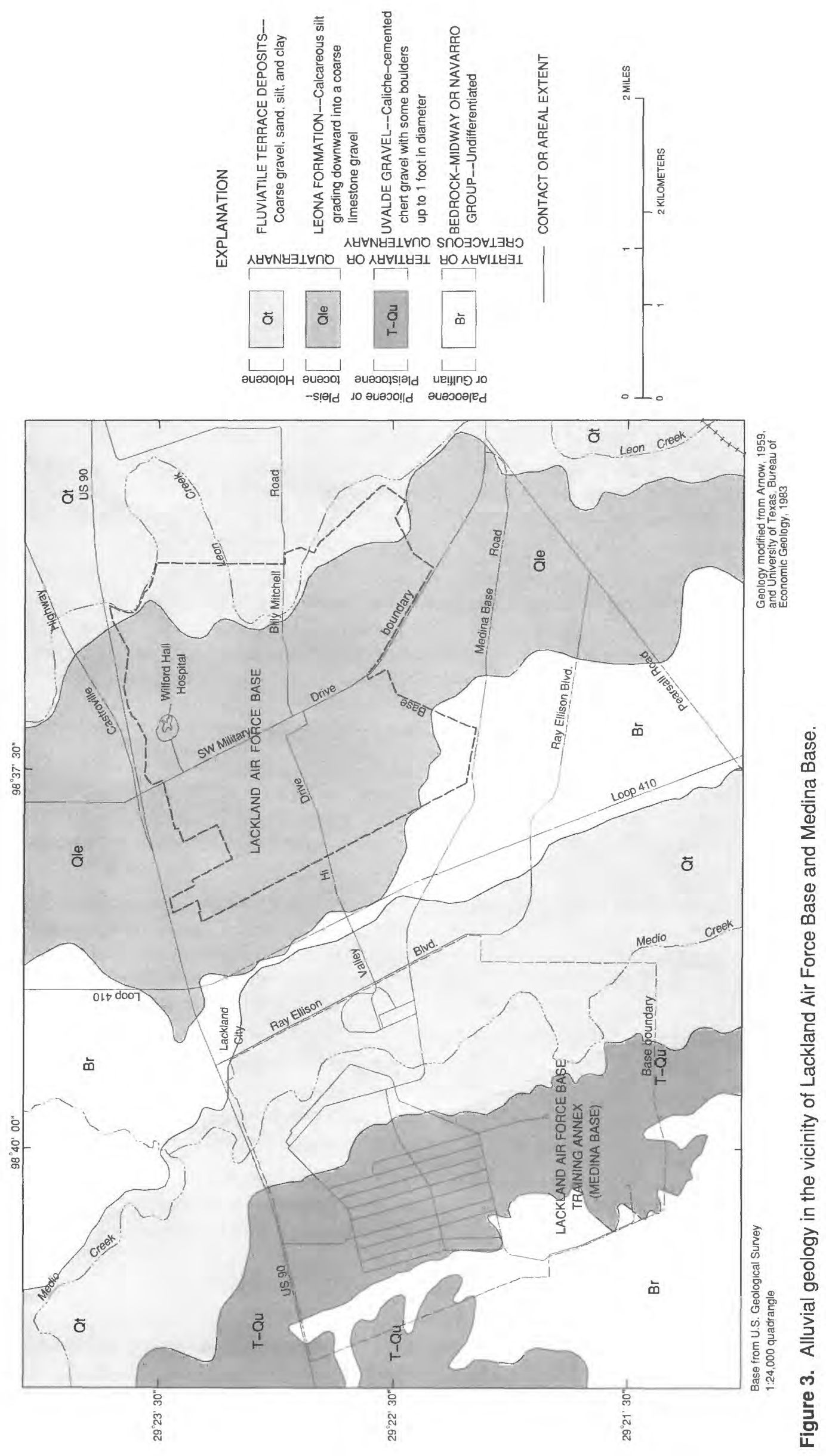
The Leona Formation overlies the Navarro and Midway Groups on most of Lackland AFB except for a small part in the southwestern corner of the base (fig. 3). The Leona Formation was not found on Medina Base. The University of Texas, Bureau of Economic Geology (1983) describes the formation as a fine calcareous silt grading downward into a coarse limestone gravel. Holt (1959) reported that the Leona Formation is composed of lenticular beds of gravel, sand, silt, and clay. The cobbles and pebbles of the gravel are predominantly limestone and some chert. Arnow (1959) reported that in Bexar County, the formation thickness ranges from 0 to $45 \mathrm{ft}$.

The fluviatile terrace deposits, composed of gravel, sand, silt, and clay, can be found along Medio Creek on Medina Base and on the eastern edge and east of Lackland AFB (fig. 3). In areas adjacent to the Edwards Plateau, the deposits are predominantly gravel of limestone, dolomite, and chert. The lithology of these deposits is similar to the Leona Formation, but is differentiated from the Leona Formation by topographic position.

\section{Alluvial Strotiaraphy}

The Uvalde Gravel is predominantly a chert gravel that is located well above current streambeds (Welder and Reeves, 1962), along divides, and on interstream ridges. A gravel-capped hill of Uvalde Gravel is located in the western part of Medina Base (fig. 3). In general, there is little or no soil above the Uvalde Gravel, and therefore, the configuration of the formation is that of land surface.

The Leona Formation consists of fluvial deposits forming terraces in the valleys of present streams. These terraces are topographically lower than those formed by the Uvalde Gravel. The Leona Formation was not present in monitoring wells or soil borings on Medina Base. The Leona Formation was present only in monitoring wells and soil borings at IRP sites (URS Consultants, 1988) and soil borings from a foundation investigation (McIntosh and Behm, 1967) on Lackland AFB. A structural contour map of the top of the Leona Formation was prepared using these data (fig. 4). The Leona Formation dips to the east toward Leon Creek. This structure might represent a flood plain of the Leon Creek where deposition of fluvial sediments occurred.

Data collected from monitoring wells and soil borings (McIntosh and Behm, 1967; URS Consultants, 1988) were used to prepare a thickness map of the Leona Formation (fig. 5). The map denotes a lenticular body south of US 90 along SW Military Drive. This lenticular body might represent the ancestral riverbed of Leon Creek.

In general, the fluviatile terrace deposits are above flood level along entrenched streams such as Leon and Medio Creeks. The Leona Formation is located above the level of these fluviatile terrace deposits. However, the fluviatile terrace deposits were encountered only in monitoring wells and soil borings at Medina Base. A structural contour map showing the top of the fluviatile terrace deposits (fig. 6) was prepared using data collected from the monitoring wells and soil borings (McIntosh and Behm, 1967; URS Consultants, 1988). The map shows that the surface east and west of Medio Creek dips toward the creek.

Data collected from monitoring wells and soil borings (McIntosh and Behm, 1967; URS Consultants, 1988) were used to prepare a thickness map of the fluviatile terrace deposits (fig. 7). The map reveals one poorly defined lenticular body south of US 90 in the central part of Medina Base. This lenticular body probably represents an alluvial channel bar belonging to the ancestral Medio Creek.

A diagrammatic geologic section is shown in figure 8 to illustrate the relation between the shallow alluvial deposits and the bedrock formations. The geologic section also illustrates the relative topographic position of each alluvial deposit.

\section{Structure}

The sedimentary rocks in Bexar County dip south-southeastward toward the Gulf of Mexico. However, in the vicinity of Lackland AFB and Medina Base, the general dip of the rocks is approximately 3 degrees to the north (McIntosh and Behm, 1967). The presence of an anticline southwest of Lackland AFB (fig. 2) is possibly indicated by the dip of the rocks and the relation between the outcrop pattern of the 


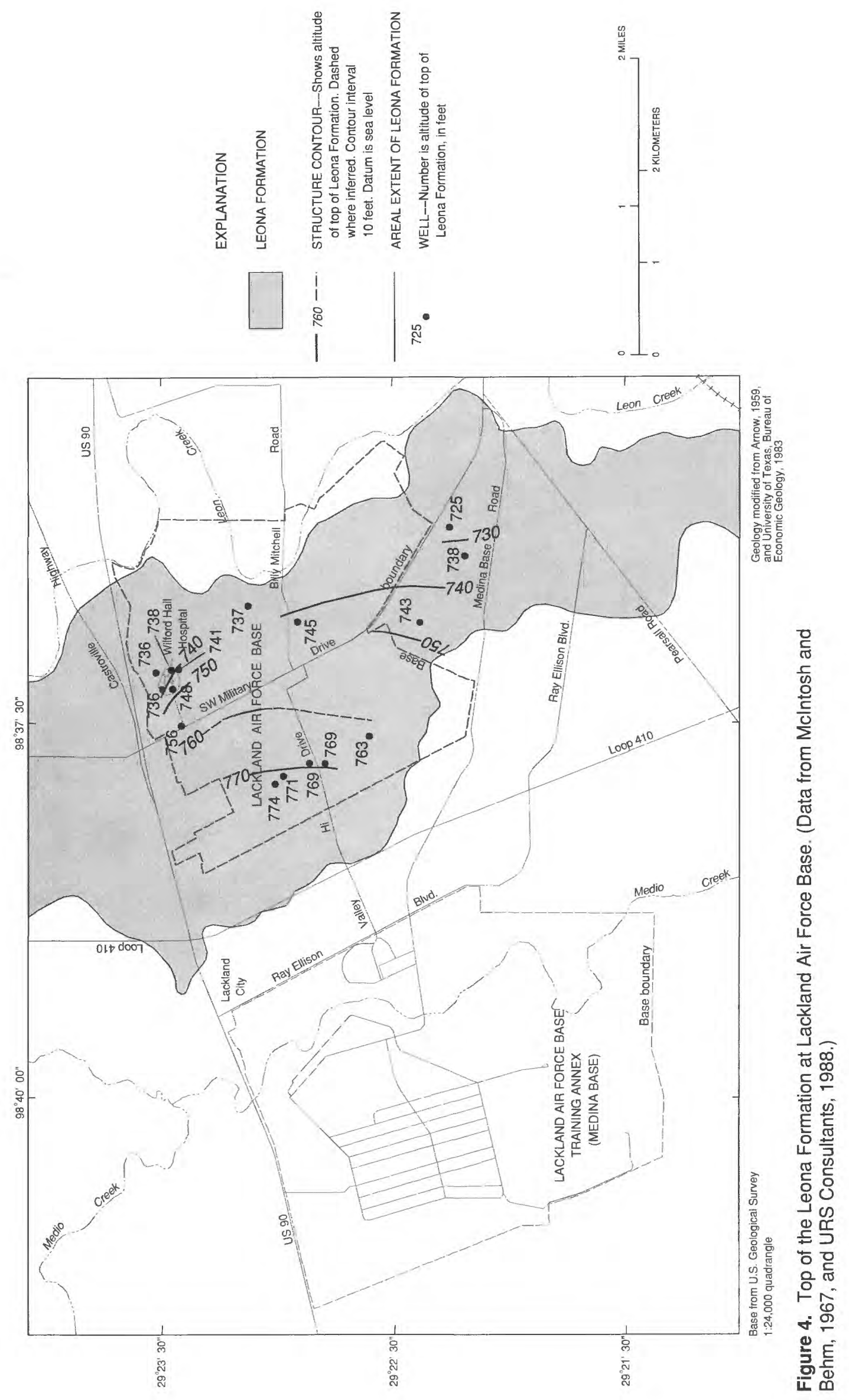



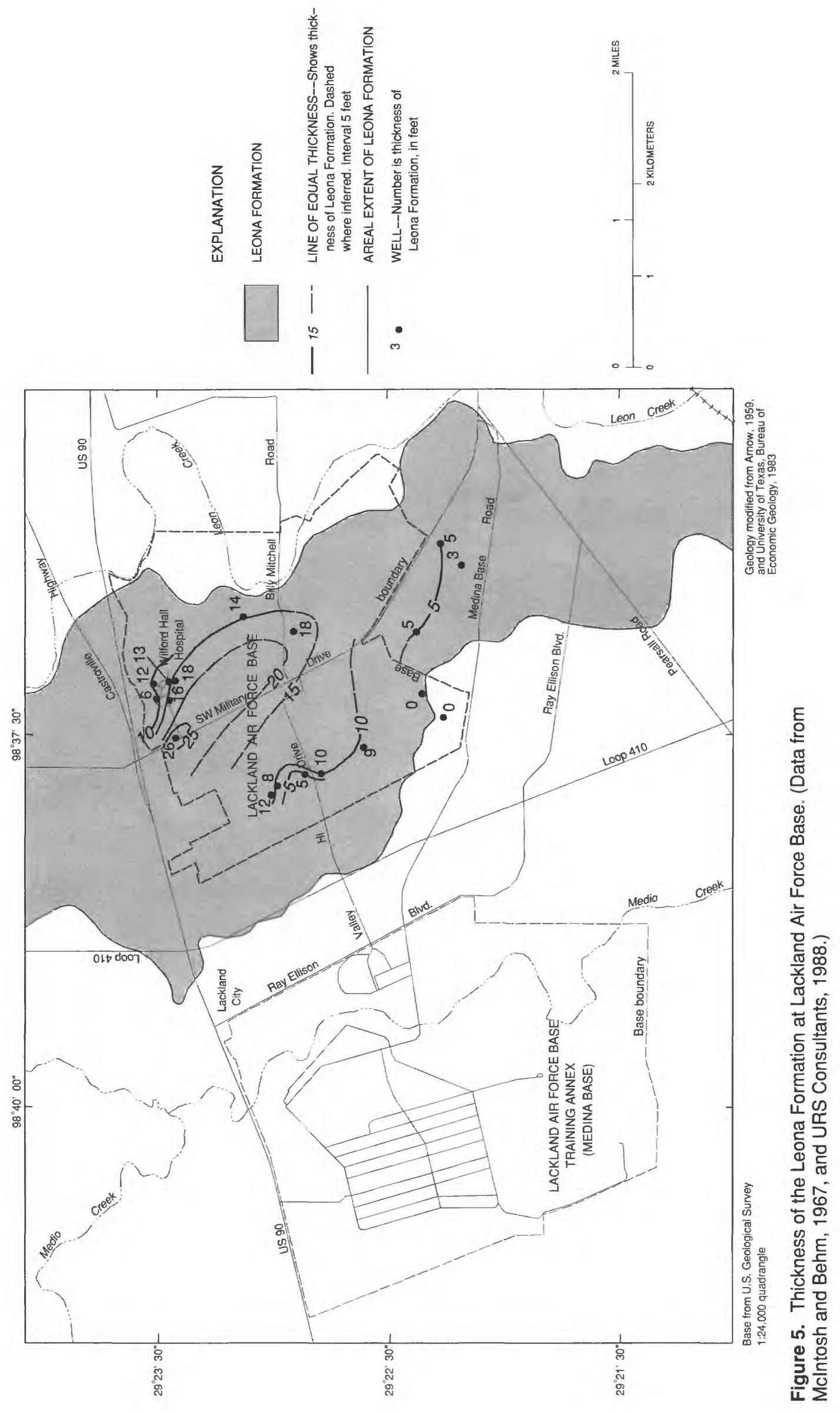


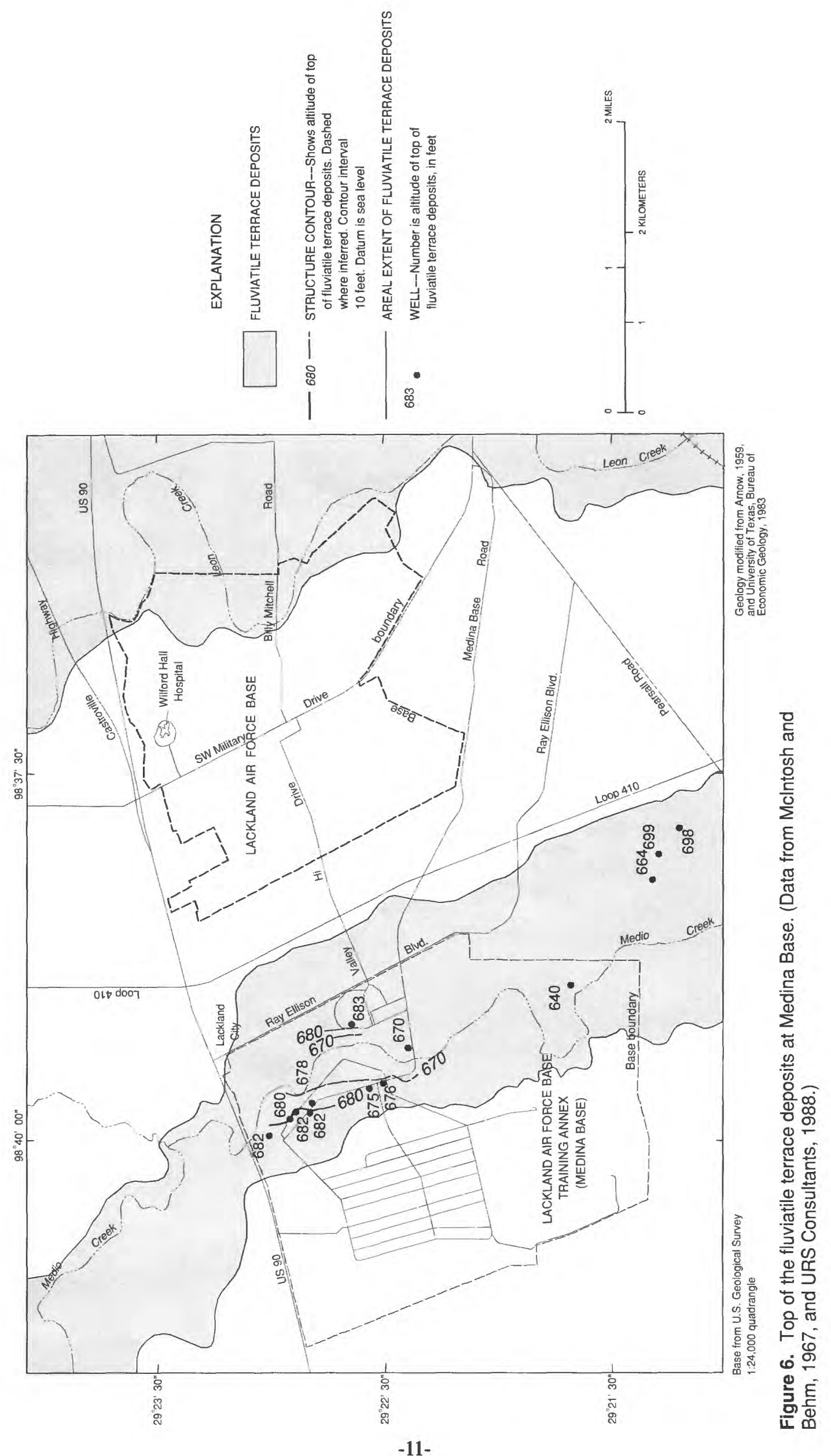




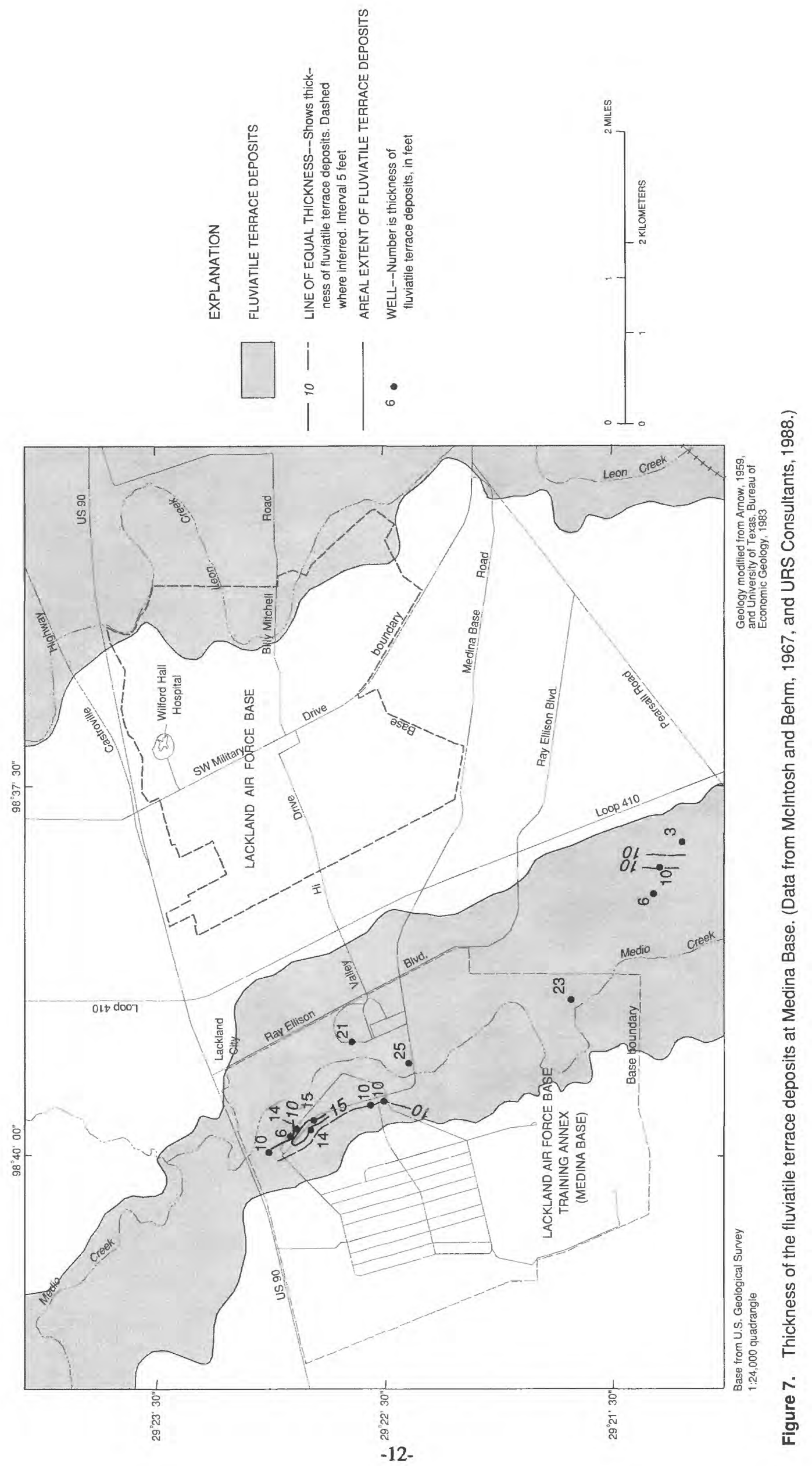



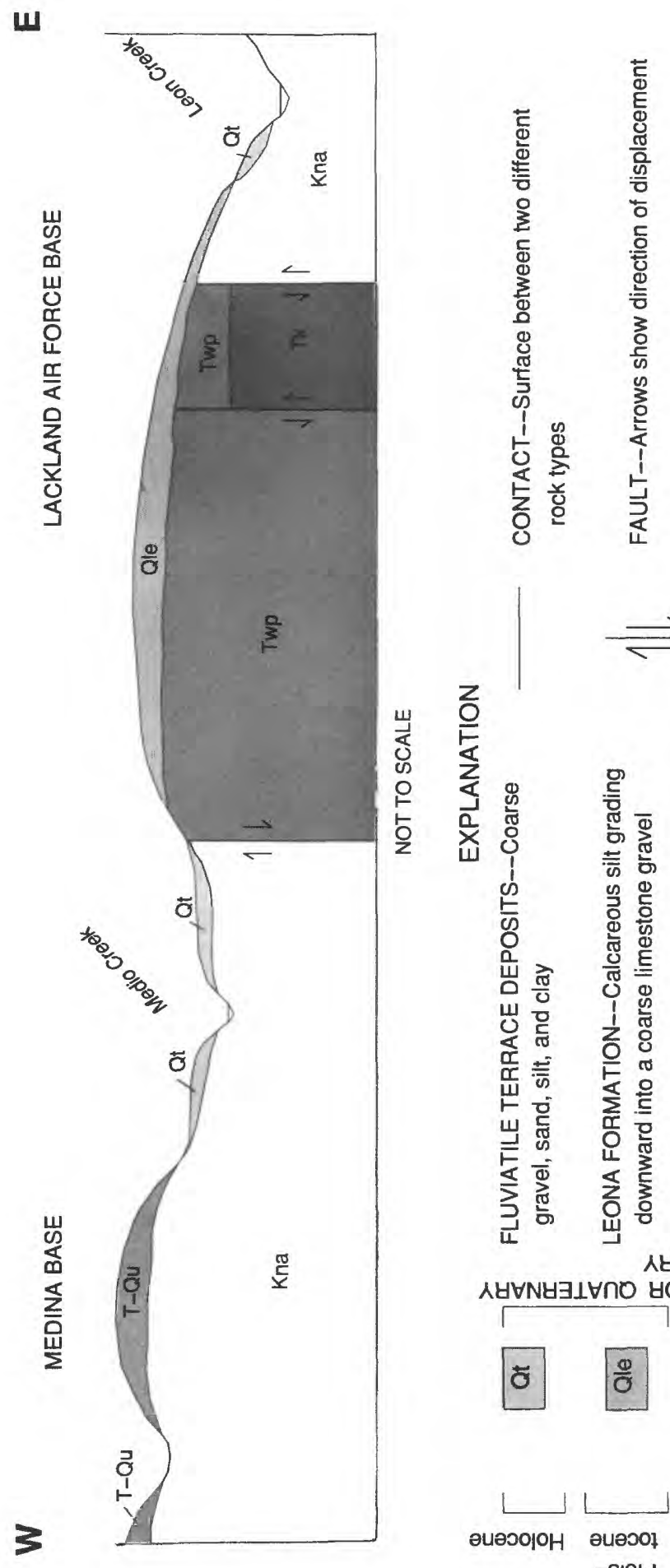

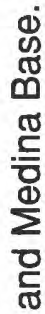

吕

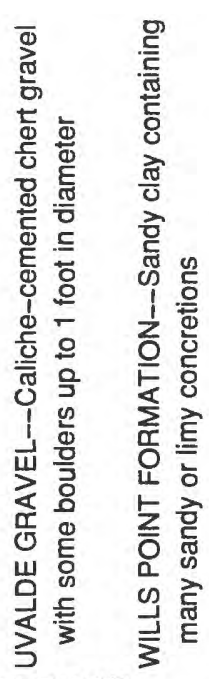

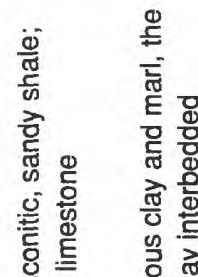

西

त्ञ 장

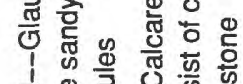

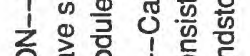

은 옫 엉

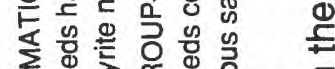

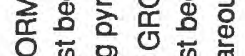

인

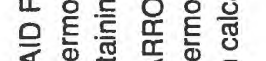

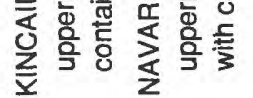
ᄉ४甘NG
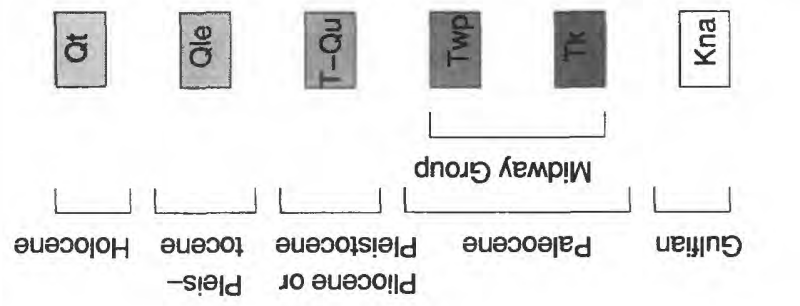

혼 
Midway and Navarro Groups (Arnow, 1959). This structure's axis strikes east-northeastward. The major faults are part of the Balcones fault zone and trend east-northeastward. Some of the major faults are intersected by cross or branch faults. The faults usually are high angle, but the fault blocks commonly are tilted along the strike of the faults. Within the study area, the fault that separates the Navarro Group from the Midway Group (fig. 2) has a throw that exceeds $550 \mathrm{ft}$ (Arnow, 1959). According to Arnow, many of these faults actually mark the trace of shatter zones. In these zones, the faults are not single sharp breaks, but a series of smaller step faults within a narrow zone (Arnow, 1959). Maclay and Small (1976) reported that local structural features within the fault zone included transverse faults, reverse faults, and down-faulted blocks on the updip side of the faults, also known as antithetic faults. These faulted areas reported by Maclay and Small (1976) are analogous to Arnow's (1959) shatter zones. One of these shatter zones appears near Wilford Hall Hospital in the northeast part of Lackland AFB (fig. 2). The alluvial geologic units--the Uvalde Gravel, the Leona Formation, and the fluviatile terrace deposits--are not affected by faulting.

\section{Alluvial Deoositional History}

The age of the faulting described in the "Structure" section of this report has not been determined accurately, but faulting probably occurred during intervals from Early Cretaceous to Holocene time. During these tectonic episodes, uplift of the Edwards Plateau might have occurred. This uplift-enhanced erosion of the Edwards Group outcrop is approximately $15 \mathrm{mi}$ north of the study area in the Edwards Plateau (fig. 1).

Sayre (1936) reported that the first movement of the Balcones faulting caused the Edwards Plateau to be uplifted. As a result, the sediment-carrying capacity of the streams, increased by the steeper channel gradient, moved large quantities of material from the Edwards Plateau. The finer material was carried long distances downstream, and the coarser, predominantly chert gravel was spread as alluvial fans immediately south of the Balcones fault zone. Welder and Reeves (1962) reported that the Uvalde deposits are predominantly chert gravel because the cobbles and pebbles composed of limestone were easily dissolved by water percolating through the formation, whereas the flint cobbles were more resistant. Erosion has removed most of the gravel and cut valleys in the ancient plain, leaving gravel-capped divides as remnants. These remnants are known as the Uvalde Gravel.

Following the deposition of the Uvalde Gravel, a period of erosion created many of the current stream valleys. Sayre (1936) theorized that another major tectonic episode rejuvenated the erosive power of the streams, and again, large quantities of gravel were spread as alluvial fans south of the Balcones fault zone. Sayre (1936) reported that these gravels from the source area are mostly limestone because the period between the first uplift and the second was too short for chemical weathering to produce a residual soil containing chert. Consequently, the Edwards Group was eroded directly and a limestone gravel resulted. The Leona Formation is composed of these gravels.

A period without substantial tectonic activity followed, and streams have downcut into the Leona Formation and reworked the gravel and other sediments to form the fluviatile terrace deposits. However, on Medina Base, the Leona Formation might not have been deposited in the area or has been eroded away. Thus, Medio Creek has downcut into the older Uvalde Gravel and has spread and reworked those gravels into the fluviatile terrace deposits. During recent geologic time, many streams have downcut into the fluviatile terrace deposits and are now entrenched without active flood plains.

\section{HYDROGEOLOGY}

The Navarro Group is not known to yield water to wells in Bexar County. However, recent studies by the U.S. Geological Survey at Kelly AFB indicate that the uppermost beds of the Navarro Group can be saturated but yield little or no water to wells (G.B. Ozuna and P.M. Buszka, U.S. Geological Survey, written commun., 1988). After reviewing well-construction records of IRP monitoring wells, it was determined that several monitoring wells were screened in the overlying water-bearing alluvial deposits and in the Navarro Group. If the possibility exists for vertical mixing of formation waters, the measurements in these monitoring wells could represent a composite static water level of the two formations. As a result, it is difficult to conclude (1) if the Navarro Group yields water to any monitoring wells at Lackland AFB and 
Medina Base, or (2) if the Navarro Group functions as a lower confining bed to all water-bearing alluvial deposits at both bases.

As with the Navarro Group, the Midway Group is not known to yield water to wells in Bexar County. The completion of wells was similar to that discussed previously, except that the wells were screened in the alluvial sediments and in the Midway Group. Again, with this type of well construction, it is difficult to conclude (1) if the Midway Group yields water to any monitoring wells at Lackland AFB and Medina Base, or (2) if the Midway Group functions as a lower confining bed to all water-bearing alluvial deposits at both military bases.

Water from the Uvalde Gravel in Bexar County has not been obtained from any known wells. Sayre (1936) also reported that the Uvalde Gravel has not yielded water to wells in the counties immediately west of Medina Base. However, during periods of precipitation, the formation can readily absorb precipitation and surface runoff. The high topographic position of the Uvalde Gravel and the substantial hydraulic conductivity of a gravel of this type (Freeze and Cherry, 1979, p. 29) allow the water in the formation to drain readily as seeps at the contact of the Uvalde Gravel and the lower confining unit.

Some wells completed in the Leona Formation west of Bexar County yield enough water for irrigation. However, the wells are not a reliable source of water because each stream terrace deposit is a separate water-bearing unit. At Lackland AFB, recharge to the Leona Formation is from the infiltration of precipitation and local irrigation from recreational and landscaped areas. Discharge from the Leona Formation occurs as small seeps and springs, and from small domestic and stock wells off base. Arnow (1959) reported that some ground water is lost by evapotranspiration. In Bexar County, along streams such as Leon Creek, the Leona Formation is thin and wells completed in the formation produce 5 to $10 \mathrm{gal} / \mathrm{min}$. Because of the limited storage capacity of the formation, domestic and stock wells off base are not dependable for water supply during droughts (Petitt and George, 1956). Holt (1959) reported that the Leona Formation contains a small quantity of water where the underlying formations are permeable but contains large quantities of water where it overlies less permeable strata.

Wells for domestic and stock use produced 5 to $10 \mathrm{gal} / \mathrm{min}$ from the fluviatile terrace deposits along the Medina River in Medina County. Each stream terrace deposit is a separate water-bearing unit. Like the Leona Formation, recharge to the fluviatile terrace deposits at Medina Base is from the direct infiltration of precipitation and local irrigation from athletic fields and landscaped areas. Discharge from the deposits can occur as small seeps and springs and, to a lesser extent, from the few domestic and stock wells that are completed in the deposits and are located off base.

Water levels were measured in three monitoring wells that were believed to be completed in the Leona Formation at Lackland AFB. Water levels in six other monitoring wells, believed to be completed in the fluviatile terrace deposits, were measured at Medina Base. Water-level maps (figs. 9 and 10) were prepared from these data. Because of the type of completion used in these monitoring wells and the lack of well control, the water-level maps are inconclusive in determining the direction of ground-water flow in the Leona Formation or fluviatile terrace deposits. However, Heath (1983) reported that, in general, ground water in the shallowest part of the saturated zone moves from interstream areas toward streams, and the depth to water is greater along the divide between streams than it is beneath the flood plain. In effect, the water-level surface usually is a subdued replica of the land surface. Therefore, under natural conditions, ground water at Lackland AFB probably moves from west to east toward Leon Creek. At Medina Base, ground water on both sides of Medio Creek probably moves toward the creek.

\section{POTENTIAL CONTAMINANT PATHWAYS}

In general, after a contaminant has reached the ground water, it tends to move laterally in the direction of ground-water flow (Bouwer, 1978). As the water moves away from the contaminant source, the concentration of contaminants decreases because of dispersion and other attenuation effects. At Lackland AFB and Medina Base, shallow ground-water flow probably is toward local streams. Major pathways of potential contaminant migration off the bases include the local streams of Medio and Leon Creeks and, to 


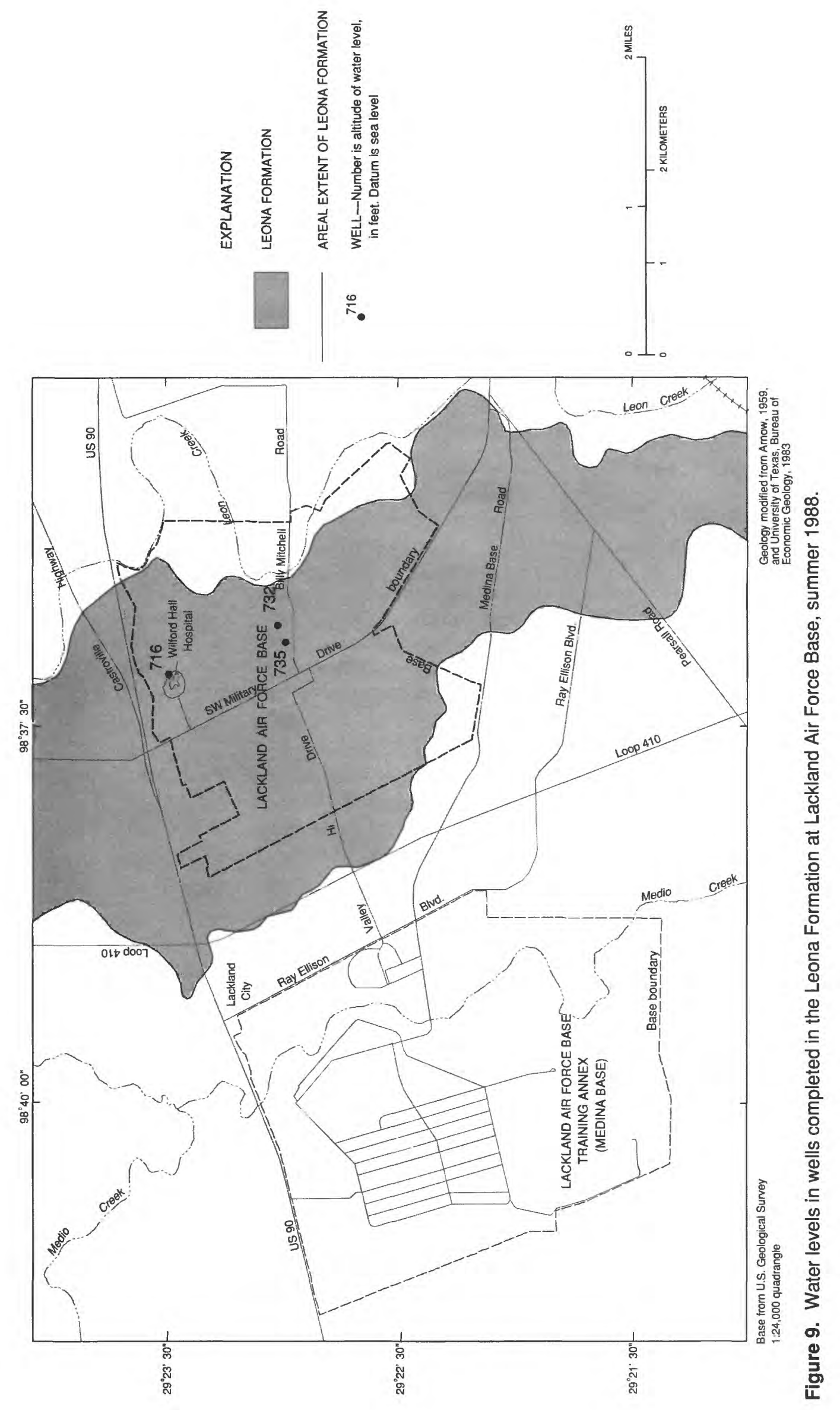



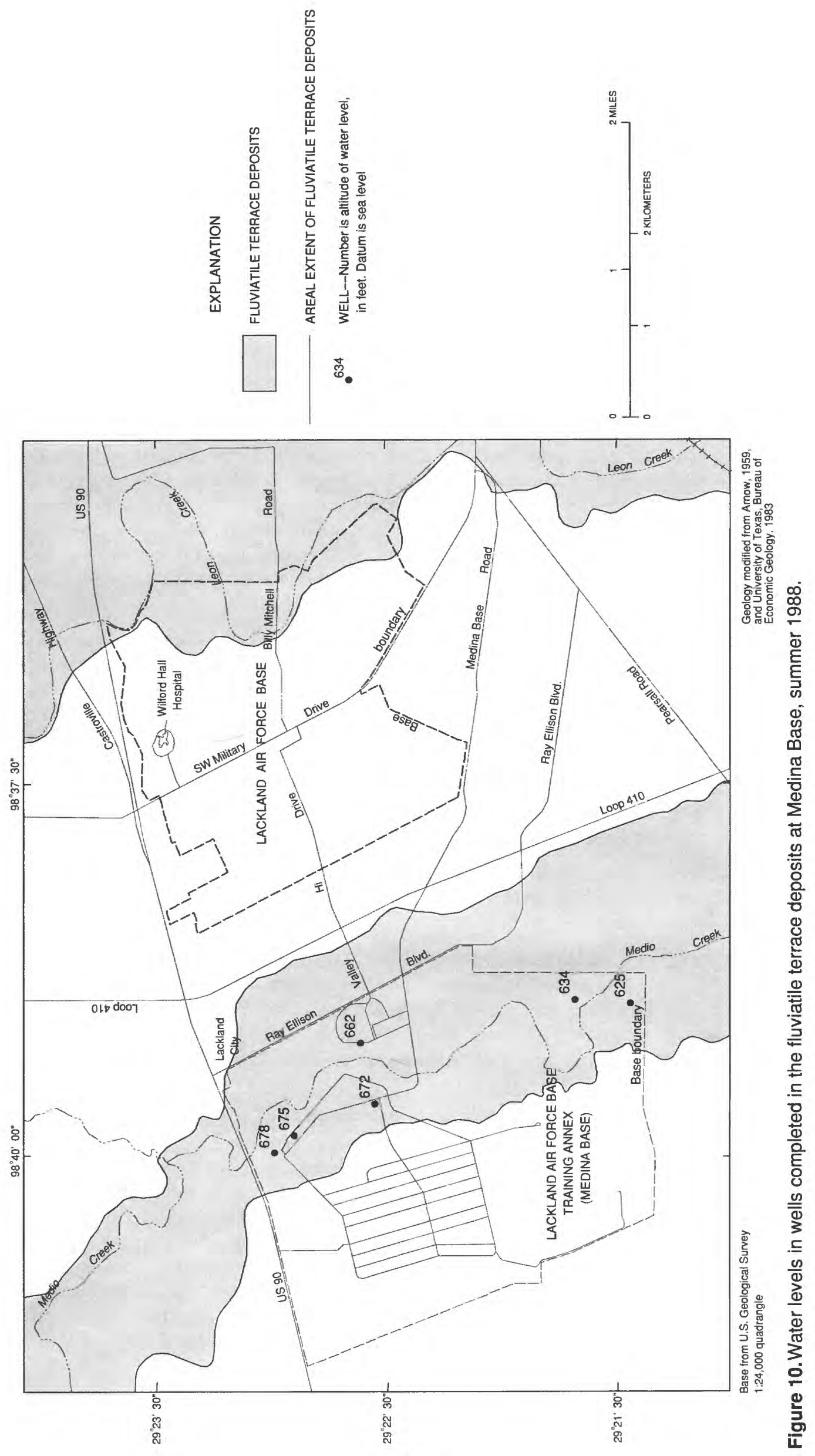
a lesser extent, the shallow ground water beneath the bases. This shallow ground water is not a source of water for local public supply.

In situations where landfills are located in relatively permeable materials such as fractured rock, gravel, or sand, leachate migration could result in contamination over areas many times larger than the areas occupied by the landfills (Freeze and Cherry, 1979). Although the Uvalde Gravel is not a source of shallow ground water at Medina Base, it has substantial hydraulic conductivity. Wastes that might be buried in the gravel could be a potential source of contamination to the ground water during recharge periods from major precipitation.

\section{CONCLUSIONS}

The geologic formations in the vicinity of Lackland AFB and Medina Base are sedimentary rocks of Cretaceous, Tertiary, and Quaternary age. The lithology of these formations consists primarily of limestone and marl, with lesser amounts of gravel, sand, silt, shale, and clay. The oldest formation at Lackland AFB and Medina Base is the Navarro Group of Late Cretaceous age. In Bexar County, the Navarro Group is mainly a calcareous clay and marl about $450 \mathrm{ft}$ thick. The uppermost beds of calcareous clay of the Navarro Group pinch out in western Bexar County and the northern part of Medina Base. Throughout the remainder of western Bexar County and in all of Medina County, upper parts of the Navarro Group are represented by the Escondido Formation. The Escondido Formation consists of flaggy, gray calcareous to argillaceous fine-grained sandstone, thin-bedded orange-yellow siltstone, gray to bluish-gray shale, and layers or lenses of sandy marl and limestone. A small outlier of the Escondido is present along Medio Creek on Medina Base.

The Midway Group of Early Tertiary age unconformably overlies the Navarro Group in the central part of Lackland AFB and Medina Base. It consists of two formations--the lower unit, known as the Kincaid Formation, and the upper unit, known as the Wills Point Formation. The Kincaid Formation is a glauconitic, sandy, greenish-gray shale overlain by an impure glauconitic, sandy, yellowish-gray limestone containing pyrite nodules. The Wills Point Formation consists mainly of sandy clay containing many sandy or limy concretions. The clays are a greenish gray and weather to a yellow brown. This coloration of the clays within the Wills Point Formation is similar to that of the upper formation of the Navarro Group and could cause difficulty in discerning one formation from the other in the field. However, the Wills Point Formation clays do not have the unctuous texture that is associated with the Navarro Group clays.

The Uvalde Gravel is the oldest and highest terrace deposit in Bexar County and is a calichecemented gravel with some boulders up to $1 \mathrm{ft}$ in diameter. The gravel consists of well-rounded cobbles of chert and some cobbles of limestone and quartz.

The Leona Formation of Pleistocene age overlies the Navarro and Midway Groups on most of Lackland AFB; however, it is not present on Medina Base. The Leona Formation is a fine calcareous silt grading downward into a coarse limestone gravel. The fluviatile terrace deposits of Holocene age along Medio Creek on Medina Base are composed of gravel, sand, silt, and clay. The lithology of these deposits is similar to the Leona Formation but is differentiated from the Leona Formation by topographic position.

The age of the faulting within the study area has not been accurately determined, but the faulting could have occurred as intervals from Early Cretaceous to Holocene time. During one of these tectonic episodes, uplift could have occurred on the Edwards Plateau. This uplift could have enhanced erosion of the Edwards Group causing deposition of alluvial deposits south of this tectonic activity. Erosion has removed most of the gravel and cut valleys in the ancient plain, leaving gravel-capped divides as remnants. These remnants are the Uvalde Gravel. Following the deposition of the Uvalde Gravel, a period of erosion created many of the current stream valleys. It is speculated that another major episode of tectonic activity ensued, and the streams again began to erode the exposed Edwards Group. The erosion resulted in fluvial deposits forming terraces in the valleys of present streams. These terraces, known as the Leona Formation, are topographically lower than the Uvalde Gravel. A period without substantial tectonic activity followed, and streams have downcut into the Leona Formation and reworked the gravel and other sediments to form the fluviatile terrace deposits. In general, the fluviatile terrace deposits are above flood level along 
entrenched streams. The Leona Formation is topographically above the level of the fluviatile terrace deposits.

The Uvalde Gravel, present only at and west of Medina Base, is not a source of shallow ground water. However, during periods of precipitation, the formation can readily absorb precipitation and surface runoff. Water drains quickly through the formation because of its high topographic position and substantial hydraulic conductivity.

Shallow ground water is present at Lackland AFB and Medina Base. At Lackland AFB, shallow ground water is present in the Leona Formation, and the flow probably is toward Leon Creek. At Medina Base, the fluviatile terrace deposits are present along both banks of Medio Creek and are separate waterbearing units. Furthermore, ground-water flow in each of these units probably is toward Medio Creek.

Major pathways of potential contaminant migration off the bases include the local streams of Medio and Leon Creeks and, to a lesser extent, the shallow ground water beneath the bases. The shallow ground water is not a source of water for local public supply. Although the Uvalde Gravel is not a source of shallow ground water at Medina Base, it drains water quickly, and wastes that might be buried in the gravel could be a potential source of contamination to the ground water during recharge periods from major precipitation.

Some of the descriptions of geology and hydrogeology presented in this report are based on a very limited database, and thus, are not considered conclusive. To improve understanding of the local geology and hydrogeology, an extensive program would be needed that includes drilling of monitoring wells, borehole geophysical logging of these wells, measuring water levels periodically, and determining yields and water quality of the wells. 


\section{REFERENCES CITED}

Arnow, Ted, 1959, Ground-water geology of Bexar County, Texas: Texas Board of Water Engineers Bulletin $5911,62 \mathrm{p}$.

Bouwer, Herman, 1978, Groundwater hydrology: New York, McGraw-Hill, 480 p.

Brucks, E.W., 1927, The geology of San Marcos quadrangle, Texas: American Association of Petroleum Geologist Bulletin 11, p. 825-851.

Fenneman, N.M., 1938, Physiography of Eastern United States: New York, McGraw-Hill, 714 p.

Freeze, R.A., and Cherry J.A., 1979, Groundwater: Englewood Cliffs, New Jersey, Prentice Hall, 604 p.

Heath, R.C., 1983, Basic ground-water hydrology: U.S. Geological Survey Water-Supply Paper 2220, 84 p.

Holt, C.L.R., Jr., 1959, Geology and water resources of Medina County, Texas: U.S. Geological Survey Water-Supply Paper 1422, 213 p.

Maclay, R.W., and Small, T.A., 1976, Progress report on geology of the Edwards aquifer, San Antonio area, Texas, and preliminary interpretations of borehole geophysical and laboratory data on carbonate rocks: U.S. Geological Survey Open-File Report 76-627, 65 p.

McIntosh, W.E., and Behm, R.C., 1967, Lackland Air Force Base, San Antonio, Texas, geological and foundation investigation: U.S. Army Corps of Engineers, 82 p.

Petitt, B.M., Jr., and George, W.O., 1956, Ground-water resources of the San Antonio area, Texas: Texas Board of Water Engineers Bulletin 5608, v. I, 80 p.; v. II, pt. III, 231 p.

Sayre, A.N., 1936, Geology and ground-water resources of Uvalde and Medina Counties, Texas: U.S. Geological Survey Water-Supply Paper 678, 146 p.

University of Texas, Bureau of Economic Geology, 1983, Geologic atlas of Texas, San Antonio sheet: Austin, scale 1:250,000.

URS Consultants, 1988, Air Force Installation Restoration Program, remedial investigation report, appendix B, Lackland Air Force Base, Texas: Sacramento, 195 p.

Welder, F.A., and Reeves, R.D., 1962, Geology and ground-water resources of Uvalde County, Texas: Texas Water Commission Bulletin 6212, 252 p. 